\title{
PROFIL KLINIKOPATOLOGI ADENOKARSINOMA PROSTAT DI RSUD DR. SAIFUL ANWAR MALANG PERIODE TAHUN 2015 - 2019: SEBUAH PENELITIAN RETROSPEKTIF
}

\author{
Kiki Ulfaningtyas ${ }^{\star 凶}$, Eviana Norahmawati', Kenty Wantri Anita*, \\ Aina Angelina*, Kurnia Penta Seputra**
}

\begin{abstract}
Abstrak
Kanker prostat adalah penyebab keganasan ke-5 pada pria di Indonesia. Atas dasar ini, dilakukan penelitian yang bertujuan untuk mengetahui profil klinikopatologi pasien yang terdiagnosis adenokarsinoma prostat di Laboratorium Patologi Anatomi RSUD Dr. Saiful Anwar (RSSA) Malang. Penelitian ini dilakukan secara deskriptif retrospektif dengan data diperoleh dari rekam medis pada Laboratorium Patologi Anatomi RSUD Dr. Saiful Anwar Malang tahun 2015-2019. Kriteria inklusi sampel penelitian adalah semua kasus yang terdiagnosis adenokarsinoma prostat secara histopatologis. Sedangkan spesimen dengan kecurigaan adenokarsinoma prostat yang masih harus dilakukan pemeriksaaan imunohistokimia dikeluarkan dari penelitian. Penelitian menunjukkan penderita adenokarsinoma prostat di Laboratorium Patologi Anatomi RSSA Malang periode tahun 2015-2019 sebanyak 84 (7,58\%) kasus, memiliki rentang umur 52-88 tahun, dengan rata-rata usia 68 tahun. Paling banyak terdiagnosis dari spesimen kerokan, sebanyak $48(57,14 \%)$ kasus. Sebagian besar diagnosis klinis sesuai dengan hasil pemeriksaan histopatologinya yakni 55 $(65,48 \%)$ kasus. Derajat diferensiasi yang terbanyak adalah poorly differentiated sebanyak $46(54,76 \%)$ kasus dan prognostic Gleason group grade terbanyak didapatkan grade 4 sebanyak $25(29,76 \%)$ kasus. Dapat disimpulkan kasus adenokarsinoma prostat rata-rata terjadi pada usia 68 tahun, paling banyak didiagnosis pada bahan kerokan. Sebagian besar kasus memiliki kesesuaian antara diagnosis klinis dan diagnosis histopatologi. Kasus yang didiagnosis umumnya termasuk dalam kategori poorly differentiated dan prognostic Gleason group grade 4.
\end{abstract}

Kata kunci: adenokarsinoma prostat, histopatologi, klinikopatologi

\section{THE CLINICOPATHOLOGICAL PROFILE OF PROSTATE ADENOCARCINOMA AT Dr. SAIFUL ANWAR PUBLIC HOSPITAL MALANG FROM 2015 TO 2019: A RETROSPECTIVE STUDY}

\begin{abstract}
Prostate cancer is the 5th cause of malignancy in men in Indonesia. This study was conducted to determine the clinicopathology profile of patients that were diagnosed as prostate adenocarcinoma in the Anatomic Pathology Department of Dr. Saiful Anwar Public Hospital Malang. We used descriptive retrospective design for this study. The data were collected from the medical record in Anatomic Pathology Department of Dr. Saiful Anwar Public Hospital Malang from 2015 to 2019. We included all patients diagnosed as prostate adenocarcarcinoma based on histopathological finding. We excluded all specimens with a suspicion of prostate adenocarcinoma which still had to be confirmed by immunohistochemical examination to establish the diagnosis. The prostate adenocarcinomas cases that fulfilled the inclusion criteria were $84(7.58 \%)$ cases. The range of patients age was $52-88$ year-old, with the average was 68 year -old. Most specimens diagnosed as adenocarcinoma prostate were most obtained from curettage specimen, with total amount $48(57.14 \%)$ cases. Clinical diagnosis was consistent with the result of histopathological test in $55(65.48 \%)$ cases. The most frequent degree of differentiation was poorly differentiated as many as $46(54.76 \%)$ cases. Prognostic Gleason group grade 4 was the most prognostic group grade as many as 25 $(29.76 \%)$ cases. To be concluded, prostate adenocarcinoma was diagnosed at the average age of 68 years, mostly found in curettage specimen. Most histopathological diagnosis had corresponding result with its clinical diagnosis. The cases had mainly poorly differentiated category and prognostic Gleason group grade 4.
\end{abstract}

Keywords: clinicopathology, histopathology, prostate adenocarcinoma

\footnotetext{
"Departmen Patologi Anatomi, Fakultas Kedokteran, Universitas Brawijaya-RSUD Dr. Saiful Anwar Malang

** Departmen Urologi, Fakultas Kedokteran, Universitas Brawijaya-RSUD Dr. Saiful Anwar Malang

E-mail:drkikityas@gmail.com
} 


\section{Pendahuluan}

Prostat adalah struktur penting pada sistem reproduksi pria yang terdiri atas kelenjar dan stroma, sekresi kelenjar prostat membentuk $30-50 \%$ dari volume cairan semen. Lesi yang ditemukan pada prostat bervariasi, meliputi lesi jinak maupun ganas. ${ }^{1}$

Kanker prostat adalah keganasan tersering pada pria dan menjadi penyebab kematian karena kanker paling utama pada pria di negara Barat. Pada tahun 2008 di Eropa didapatkan 94.000 kematian akibat kanker prostat dan lebih dari 28.000 kematian di Amerika Serikat pada 2012.2 Barnes (1969) menemukan angka kesintasan 10 tahun dan 15 tahun untuk kanker prostat stadium dini hanya sebesar $50 \%$ dan $30 \%{ }^{3}$ Rasio insidensi terhadap mortalitas sebesar 5,3 pada tahun 2000. Di Asia, insiden kanker prostat rata-rata adalah 7,2 per 100.000 pria per tahun. ${ }^{2} \mathrm{Di}$ Indonesia, jumlah penderita kanker prostat di tiga RS pusat pendidikan (Jakarta, Surabaya dan Bandung) selama 8 tahun terakhir adalah 1.102 pasien dengan rerata usia 67,18 tahun. Menurut data Badan Registrasi Kanker tahun 2014, di Malang tumor prostat menduduki urutan ketiga tumor primer tersering pada laki-laki.2,4 Menurut Global on Cancer (Globlocan) 2020, kanker prostat menduduki peringkat ke-5 sebagai penyebab kanker pria di Indonesia. ${ }^{5}$

Di Indonesia penderita kanker prostat sering datang pada stadium lanjut dan didapatkan angka sebesar $59,3 \%$ kasus. Terapi primer yang terbanyak dipilih adalah orkhidektomi sebesar $31,1 \%$, obat hormonal $182(18 \%)$, prostatektomi radikal $89(9 \%)$, radioterapi $63(6 \%)$, sisanya adalah pemantauan aktif, kemoterapi dan kombinasi. Modalitas diagnostik yang digunakan terutama biopsi $57,9 \%$. $^{2}$

Adenokarsinoma prostat adalah karsinoma invasif yang terdiri dari sel epitel neoplastik prostatik dengan diferensiasi sekresi yang disusun dalam berbagai pola histo- morfologi, termasuk glands, cords, single cells, dan sheets. Sel basal biasanya tidak didapatkan. Adenokarsinoma prostat adalah bentuk keganasan prostat yang tersering, sehingga terminologi kanker prostat seringkali mengacu pada adenokarsinoma prostat.2,5

Sekitar 95\% kanker prostat ganas adalah adenokarsinoma tipe asinar, dan berasal dari sel epitel prostat. Diagnosis histopatologi karsinoma prostat didasarkan pada gambaran morfologi. Varian histologis kanker prostat meliputi adenokarsinoma asinar prostat, adenokarsinoma duktal, tumor neuroendokrin, dan karsinoma lainnya. 6,7

Berdasarkan gambaran mengenai adenokarsinoma prostat, serta insidensinya baik secara global maupun regional, maka peneliti merasa tertarik untuk meneliti adenokarsinoma prostat, bagaimana angka kejadian beserta karakteristik klinikopatologiknya secara lokal di Laboratorium Patologi Anatomi RSUD Dr. Saiful Anwar Malang. Hal ini karena adenokarsinoma prostat merupakan kanker organ reproduksi pria dengan insiden tinggi dan sangat berbeda tatalaksana maupun prognosisnya dengan lesi jinak pada prostat. Selain itu, belum ada penelitian yang serupa di Laboratorium Patologi Anatomi RSUD Dr. Saiful Anwar Malang. Hasil akhir dari penelitian ini diharapkan dapat dijadikan dasar untuk mempermudah penegakan diagnosis berdasarkan data epidemiologi seta sebagai dasar untuk evaluasi bagi klinisi maupun ahli patologi anatomi mengenai diagnosis dan terapi.

\section{Bahan dan Metode}

\section{Sampel Penelitian}

Penelitian ini dirancang menggunakan desain penelitian deskriptif untuk mengetahui karakteristik klinis dan histopatologis dari kasus adenokarsinoma prostat di Laboratorium Patologi Anatomi RSUD Dr. Saiful Anwar Malang yang diambil dalam rentang waktu mulai tahun 2015 hingga 2019. 
Pengambilan data dilakukan secara retrospektif dengan mengumpulkan data sekunder berupa rekam medis penderita yang telah diperiksa di Laboratorium Patologi Anatomi RSUD Dr. Saiful Anwar Malang.

Kriteria inklusi pada penelitian ini adalah semua penderita yang telah diperiksa sediaan histopatologi hasil operasi, kerokan maupun biopsinya dan didiagnosis sebagai adenokarsinoma prostat di Laboratorium Patologi Anatomi RSUD Dr. Saiful Anwar Malang dengan bahan yang diterima mulai tahun 2015 hingga 2019. Sedangkan kriteria eksklusi adalah spesimen dengan kecurigaan adenokarsinoma prostat yang masih harus dilakukan pemeriksakan imunohistokimia untuk konfirmasi diagnosis di Laboratorium Patologi Anatomi RSUD Dr Saiful Anwar Malang. Pemilihan sampel pada penelitian ini menggunakan teknik total sampling.

\section{Karakteristik Klinikopatologi \\ Karakteristik klinikopatologi adalah} komponen-komponen yang akan diteliti pada penderita yaitu (1). Insiden: Angka kejadian adenokarsinoma prostat diantara lesi prostat lainnya, (2). Umur: Umur pasien saat terdiagnosa, dikategorikan dalam satuan tahun, (3). Metode: Metode pengambilan sampel jaringan penderita adenokarsinoma prostat, (4). Kesesuaian diagnosa/keterangan klinis dengan diagnosa histopatologi: Diagnosis/keterangan klinis yang tercantum dalam formulir permintaan histopatologi dilihat kesesuaiannya dengan hasil pemeriksaan histopatologi. Diagnosis klinis adalah kecurigaan klinis terhadap sediaan yang dikirimkan baik dari hasil pemeriksaan fisik, radiologis, maupun laboratoris, (5). Derajat diferensiasi: Derajat diferensiasi adenokarsinoma prostat dinilai dengan sistem skor Gleason, yang kemudian dikelompokan menjadi 3 derajat diferensiasi, yaitu terdiri dari well differentiated untuk skor Gleason $\leq 6$, moderate differentiated untuk skor Gleason 7 dan poorly differentiated untuk skor Gleason 8 -10, (6). Prognostic Group Grade: Faktor prognostik dan prediksi pada kanker prostat dapat dinilai menggunakan Prognostic Gleason Group Grade sebagai berikut: Gleason score $\leq 6$ : Prognostic Group grade I/ V; Gleason score 3+4 = 7: Prognostic Group grade IIIN; Gleason score 4+3 = 7: Prognostic Group grade III/V; Gleason Score 8: Prognostic Group grade IV/V; Gleason score 9-10: Prognostic Group grade VN.

\section{Hasil}

Insiden Adenokarsinoma Prostat

Setelah dilakukan penghitungan dari data rekam medis yang terdapat di Laboratorium Patologi Anatomi RSUD Dr. Saiful Anwar periode tahun 2015 hingga 2019, didapatkan sebanyak 84 laki laki yang terdiagnosis adenokarsinoma prostat, dari 1108 spesimen dengan lesi prostat yang diperiksa di Laboratorium Patologi Anatomi RSUD Dr. Saiful Anwar Malang (Gambar 1). Rincian kasus adenokarsinoma prostat per tahun dibandingkan lesi prostat lainnya disajikan pada Gambar 2-6, sedangkan rincian kasus adenokarsinoma selama 5 tahun ditunjukkan pada Gambar 7.

Data yang diperoleh dari rekam medis Laboratorium Patologi Anatomi RSUD Dr. Saiful Anwar Malang selama tahun 2015 menunjukkan bahwa kasus adenokarsinoma prostat sebanyak 27 (8,46\%) kasus, dari 319 kasus lesi prostat yang dikirimkan (Gambar 2). Lalu, selama tahun 2016 mendapatkan kasus adenokarsinoma prostat sebanyak 8 $(3,83 \%)$ kasus, dari 209 kasus lesi prostat yang dikirimkan (Gambar 3). Selama tahun 2017 mendapatkan kasus adenokarsinoma prostat sebanyak 14 (10,07\%) kasus, dari 139 kasus lesi prostat yang dikirimkan (Gambar 4). 


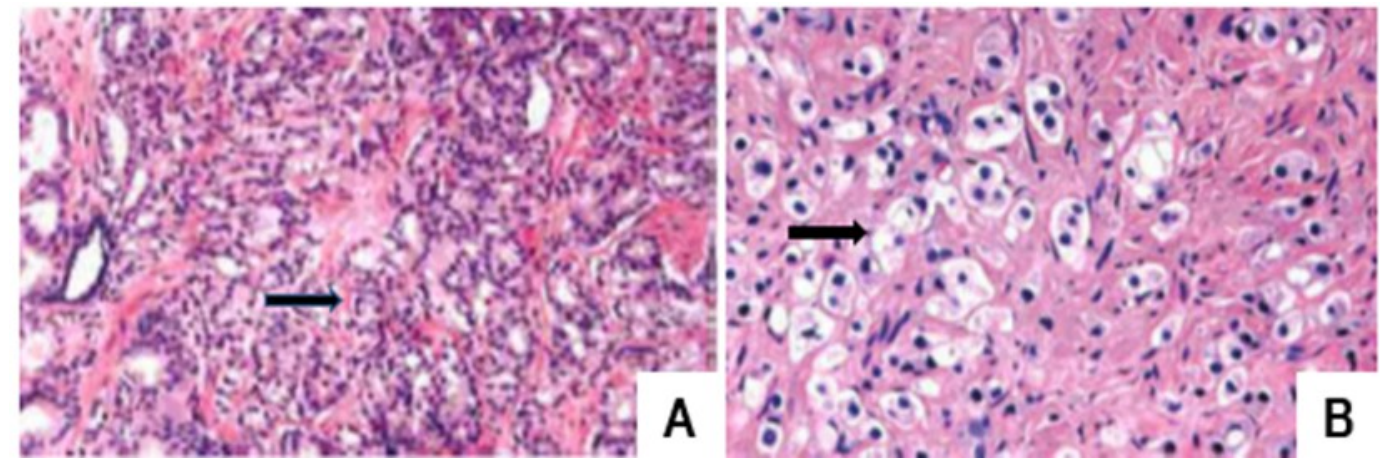

Gambar 1. Histopatologi adenokarsinoma prostat (400x)

Keterangan: (A). Gleason score $7(4+3)$, predominant fused gland, (B). Gleason score $10(5+5)$, terdiri atas sel-sel individual $(\text { single })^{8}$

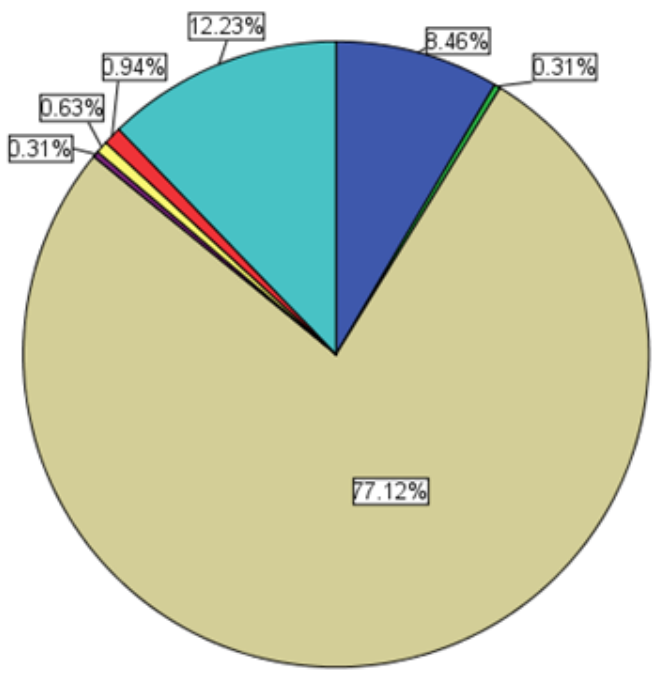

$$
\begin{aligned}
& \text { Diagnosis Histopatologi } \\
& \text { GAdenokarsinoma prostat } \\
& \text { GBenign mesenchymal tumor } \\
& \text { GBenign Prostat Hiperplasia } \\
& \text { GLow Grade PNN } \\
& \text { Brostatis kronis } \\
& \text { Bsel atipik } \\
& \square \text { tidak didapatkan sel ganas }
\end{aligned}
$$

Gambar 2. Hasil pemeriksaan histopatologi sediaan jaringan prostat di Laboratorium Patologi Anatomi RSUD Dr. Saiful Anwar Malang tahun 2015
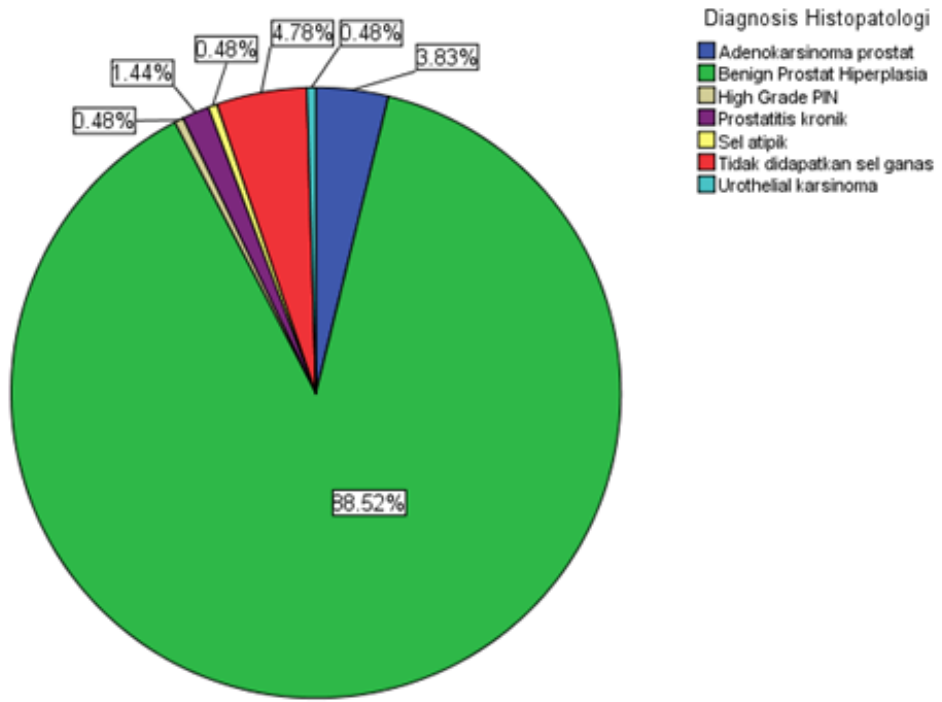

Gambar 3. Hasil pemeriksaan histopatologi sediaan jaringan prostat di Laboratorium Patologi Anatomi RSUD Dr. Saiful Anwar Malang tahun 2016 


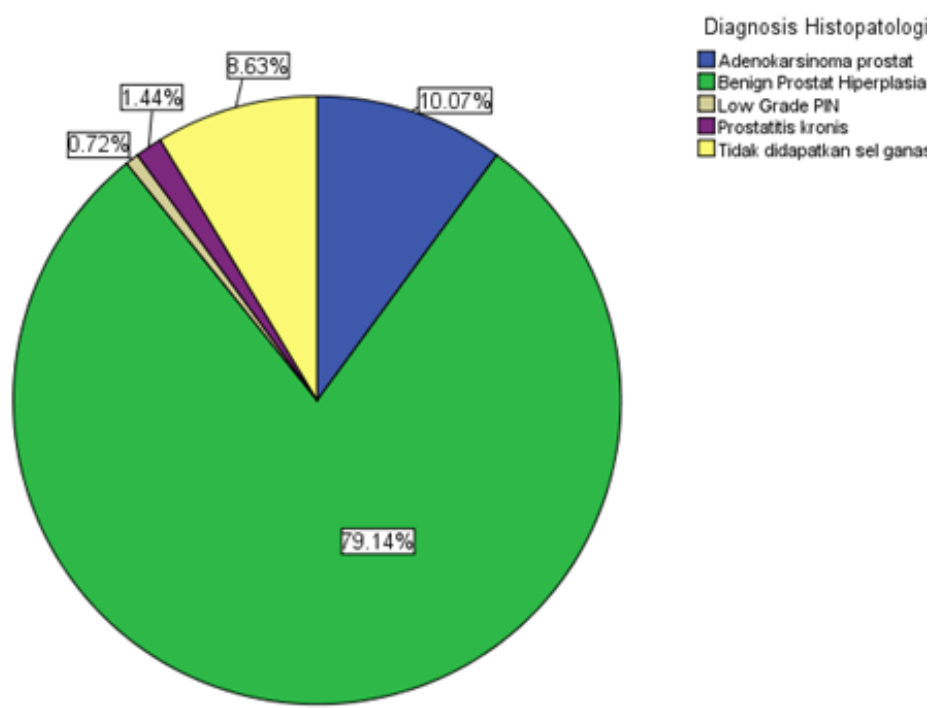

Gambar 4. Hasil pemeriksaan histopatologi sediaan jaringan prostat di Laboratorium Patologi Anatomi RSUD Dr. Saiful Anwar Malang tahun 2017

Data yang diperoleh dari rekam medis Laboratorium Patologi Anatomi RSUD Dr. Saiful Anwar Malang selama tahun 2018 menunjukkan bahwa kasus adenokarsinoma prostat sebanyak $18(7,29 \%)$ kasus, dari 247 kasus lesi prostat yang dikirimkan (Gambar 5). Kemudian selama tahun 2019 mendapatkan kasus adenokarsinoma prostat sebanyak 17 (8,76\%) kasus, dari 194 kasus lesi prostat yang dikirimkan (Gambar 6). Data yang diperoleh selama tahun 2015-2019 menunjukkan bahwa kasus adenokarsinoma prostat sebanyak 84 (7,58\%) kasus, dari 1108 kasus lesi prostat yang dikirimkan (Gambar 7).

Selanjutnya dari 84 kasus yang ditemukan, akan dikategorikan dan dilihat distribusinya berdasarkan umur, metode pengambilan spesimen, kesesuaian diagnosa klinis dan histopatologi, derajat keganasan, serta prognostic group grade sesuai klasifikasi WHO 2016.
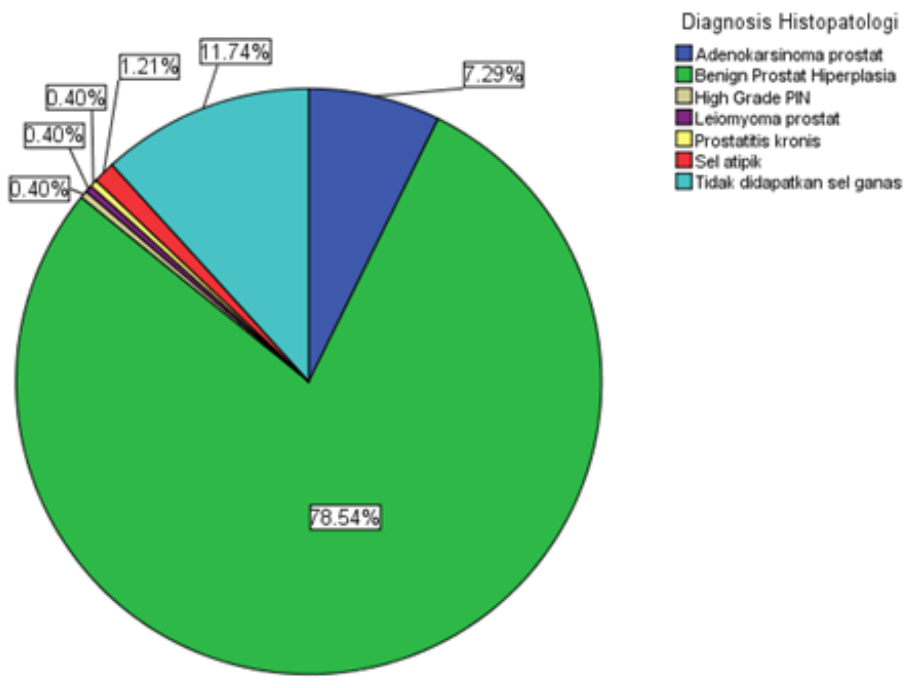

Gambar 5. Hasil pemeriksaan histopatologi sediaan jaringan prostat di Laboratorium Patologi Anatomi RSUD Dr. Saiful Anwar Malang tahun 2018 


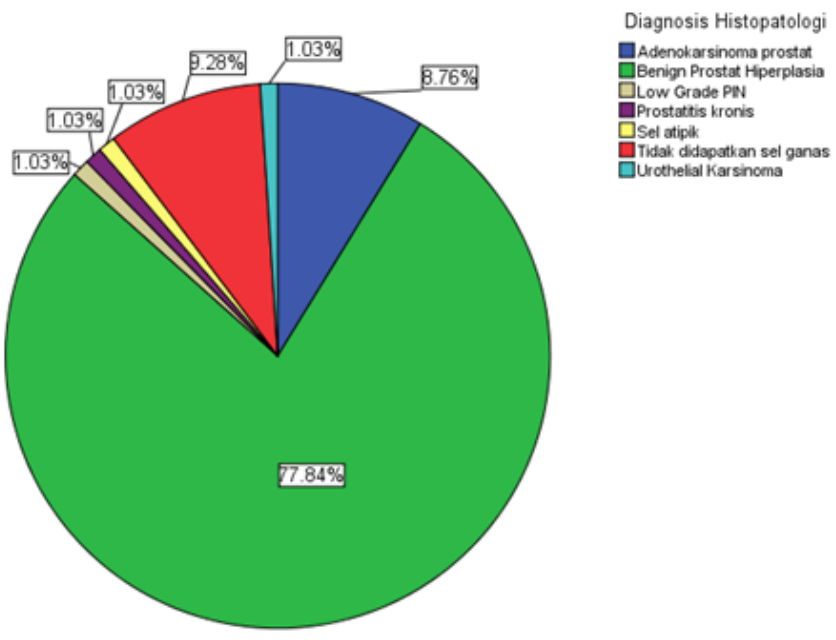

Gambar 6. Hasil pemeriksaan histopatologi sediaan jaringan prostat di Laboratorium Patologi Anatomi RSUD Dr. Saiful Anwar Malang tahun 2019

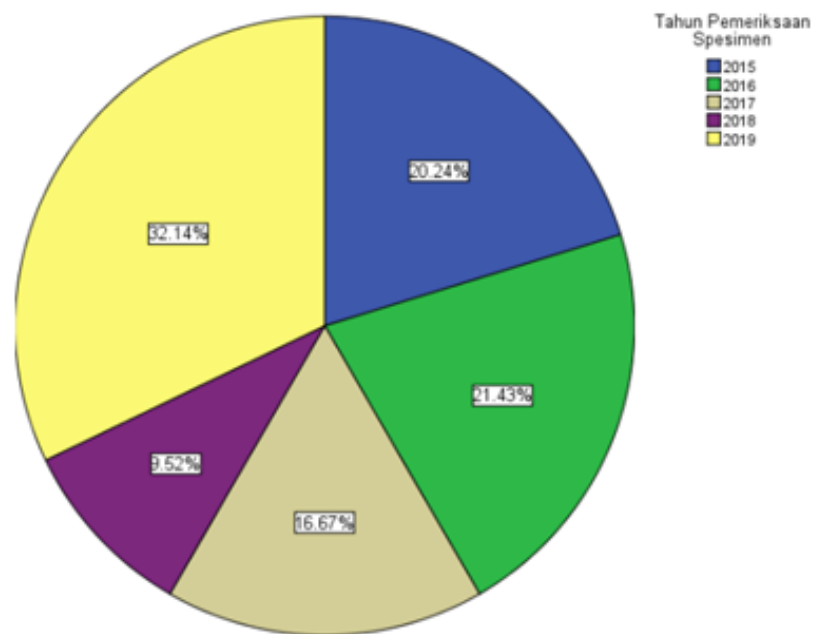

Gambar 7. Jumlah kasus adenokarsinoma prostat di Laboratorium Patologi Anatomi RSUD Dr. Saiful Anwar Malang Periode 2015-2019

\section{Rerata Usia Adenokarsinoma Prostat}

Dari 84 penderita adenokarsinoma prostat di Laboratorium Patologi Anatomi RSUD Dr. Saiful Anwar Malang dalam kurun waktu 5 tahun ditemukan pada rentang usia tua yaitu sekitar 52-88 tahun, dengan ratarata usia 68,07 tahun, dengan standar deviasi 8,22. Umur termuda yang ditemukan adalah 52 tahun, sedangkan umur tertua adalah 88 tahun. Selanjutnya, data dikelompokkan menurut dekade usia, ditentukan rerata dan standard deviasi masing-masing kelompok usia. Adenokarsinoma prostat terbanyak ditemukan pada kelompok usia 60-70 tahun, yaitu sebanyak 39 spesimen dengan rerata usia 65,23 tahun dan standard deviasi 2,814 (Gambar 8).

Distribusi Adenokarsinoma Prostat Berdasarkan Metode Pengambilan Sampel Jaringan

Data yang diperoleh dari rekam medis Laboratorium Patologi Anatomi RSUD Dr. Saiful Anwar Malang selama tahun 20152019 menunjukkan bahwa adenokarsinoma prostat paling banyak terdiagnosis dari spesimen kerokan sebanyak $48 \quad(57,14 \%)$ kasus, dibandingkan dengan biopsi dan operasi (Gambar 9). 


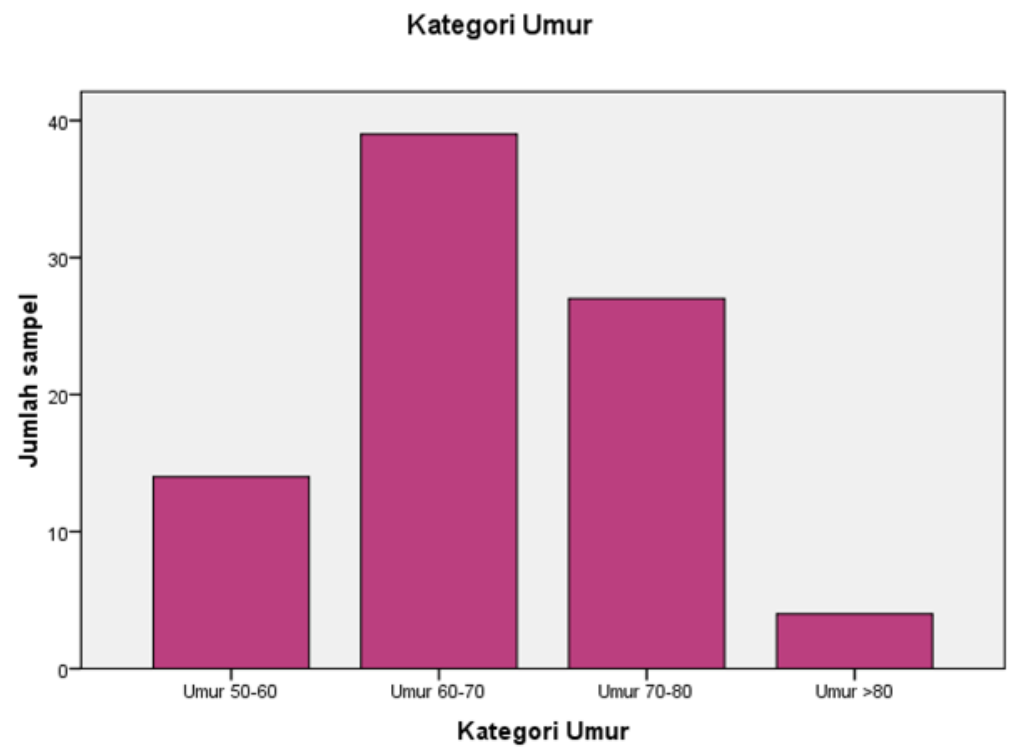

Gambar 8. Distribusi usia pasien karsinoma prostat di RSUD Dr. Saiful Anwar Malang tahun 2015-2019

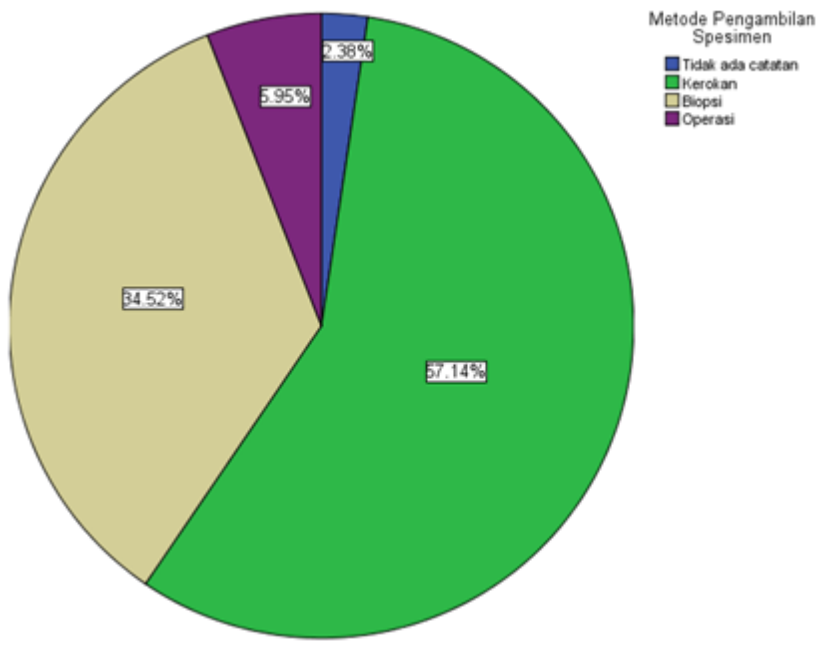

Gambar 9. Distribusi adenokarsinoma prostat berdasarkan metode pengambilan sampel jaringan di Laboratorium Patologi Anatomi RSUD Dr. Saiful Anwar Malang tahun 2015-2019

Distribusi Adenokarsinoma Prostat Berdasarkan Kesesuaian Diagnosa Klinis dengan Diagnosis Histopatologi

Dalam data rekam medik tercatat diagnosis/keterangan klinis dari setiap sediaan yang dikirimkan untuk dilakukan pemeriksaan di Laboratorium Patologi Anatomi RSUD Dr. Saiful Anwar Malang. Berdasarkan data yang diperoleh selama tahun 2015-2019, dari 84 kasus adenokarsinoma prostat tahun 2015-2019, didapatkan 55 kasus $(65,48 \%)$ dengan diagnosis yang sesuai dengan pemeriksaan histopatologinya dan sisanya sekitar 22 kasus $(26,19 \%)$ masih kurang sesuai atau kurang akurat, sedangkan 7 $(8,33 \%)$ kasus tidak didapatkan keterangan klinis (Gambar 10). 


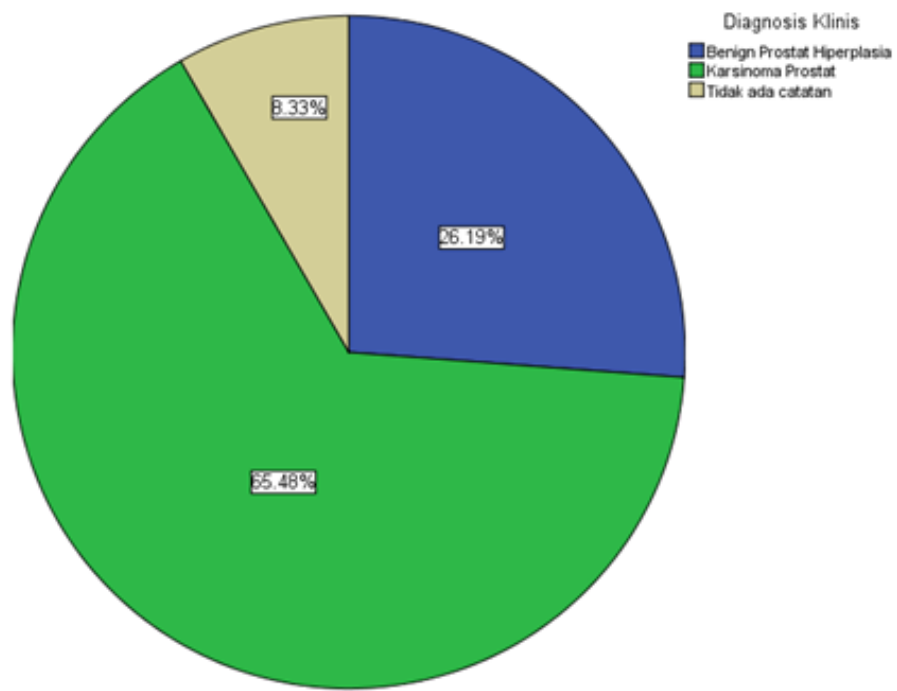

Gambar 10. Diagnosis klinis pasien karsinoma prostat sebelum dilakukan pemeriksaan histopatologi

\section{Distribusi Adenokarsinoma Prostat} Berdasarkan Derajat Keganasan

Adenokarsinoma prostat yang ditemukan di Laboratorium Patologi Anatomi RSUD Dr. Saiful Anwar Malang periode tahun 2012-2019 dilakukan penilaian skor Gleason pada masing masing spesimen, kemudian dikelompokkan derajat diferensiasinya menjadi 3 kelompok yakni, well differentiated, moderate differentiated, dan poorly differentiated. Distribusi adenokarsinoma terbanyak didapatkan pada derajat diferensiasi poorly differentiated, dengan jumlah kasus sebanyak $46(54,76 \%)$ (Gambar 11).

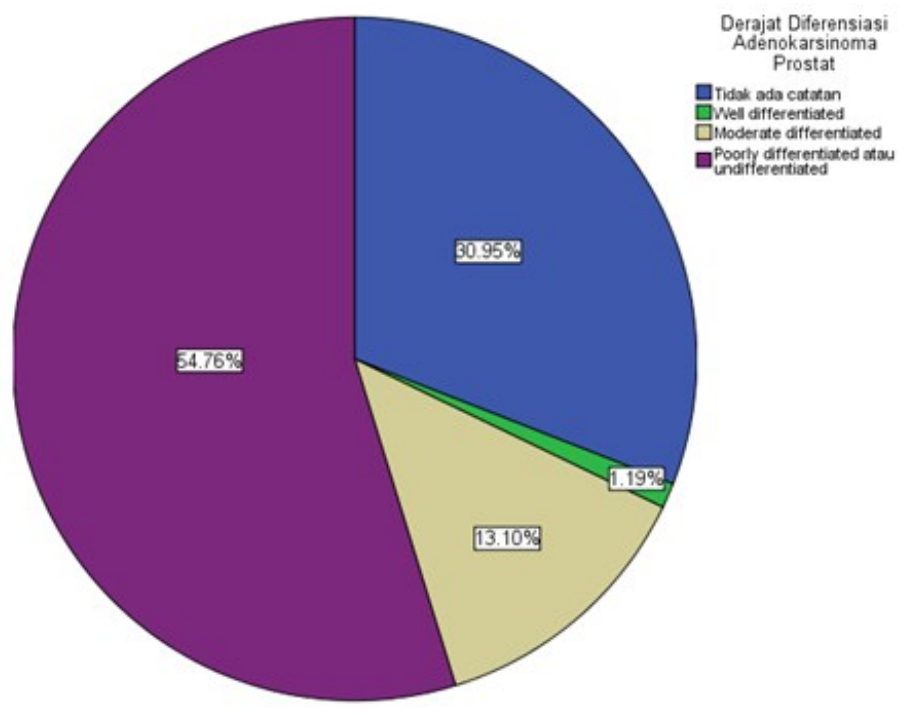

Gambar 11. Derajat diferensiasi pasien adenokarsinoma prostat di RSUD Dr. Saiful Anwar Malang tahun 2015-2019 


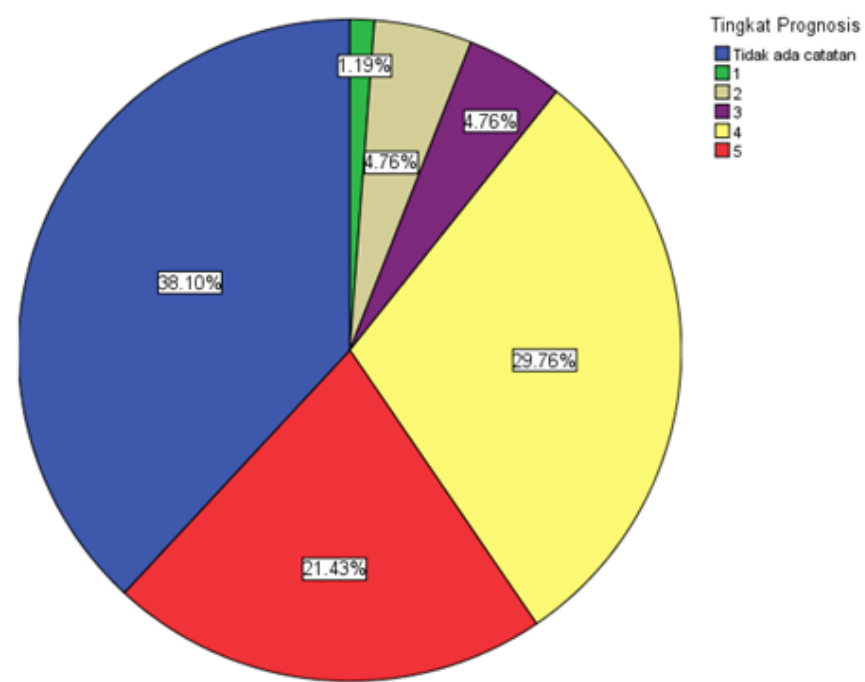

Gambar 12. Distribusi adenokarsinoma prostat berdasarkan prognostic group grade di Laboratorium Patologi Anatomi RSUD Dr. Saiful Anwar Malang tahun 2015-2019

\section{Pembahasan}

\section{Insiden Adenokarsinoma Prostat}

Selama kurun waktu 5 tahun yaitu tahun 2015 hingga 2019 didapatkan sebanyak 84 kasus adenokarsinoma prostat berdasarkan rekam medik penderita di Laboratorium Patologi Anatomi RSUD Dr. Saiful Anwar Malang. Hal ini menunjukkan bahwa di Malang Indonesia, angka kejadian adenokarsinoma prostat sebanyak $7,58 \%$ dari kasus lesi prostat yang diperiksa, sesuai dengan literatur yang menyebutkan bahwa di Asia, insiden kanker prostat rata-rata adalah 7,2 per 100.000 pria per tahun. ${ }^{2}$

\section{Rerata Usia Adenokarsinoma Prostat}

Dari 84 penderita adenokarsinoma prostat di Laboratorium Patologi Anatomi RSUD Dr. Saiful Anwar Malang dalam kurun waktu 5 tahun, adenokarsinoma prostat ditemukan pada rentang usia tua yaitu 52-88 tahun, dengan rata-rata usia 68,07 tahun, dengan standar deviasi 8,22. Umur termuda yang ditemukan adalah 52 tahun. Sedangkan umur tertua yang ditemukan adalah 88 . Adenokarsinoma prostat terbanyak ditemukan pada kelompok usia 60-70 tahun, yaitu sebanyak 39 spesimen, dengan rerata usia 65,23 .
Hal ini sesuai dengan literatur yang menyebutkan bahwa adenokarsinoma prostat banyak diderita oleh laki laki usia tua, WHO menyebutkan bahwa adenokarsinoma prostat banyak diderita oleh laki laki usia lebih dari 60 tahun. ${ }^{3}$ Seperti pada sebagian besar kanker, usia dan asal etnis adalah faktor risiko terkuat yang diketahui sebagai pemicu timbulnya kanker selain faktor risiko lain yang tidak kalah penting, seperti keterlibatan hormon androgen pada adenokarsinoma prostat. ${ }^{8}$

\section{Distribusi Adenokarsinoma Prostat Berdasarkan Metode Pengambilan Sampel Jaringan}

Data yang diperoleh dari rekam medis Laboratorium Patologi Anatomi RSUD Dr. Saiful Anwar Malang selama tahun 2015-2019 menunjukkan bahwa adenokarsinoma prostat paling banyak terdiagnosis dari spesimen kerokan $48(57,14 \%)$ dibandingkan dengan biopsi dan operasi. Hal ini tidak sesuai dengan penelitian sebelumnya bahwa modalitas diagnostik yang digunakan untuk penegakan diagnosis terutama adalah spesimen biopsi $57.9 \% .^{2}$ Ketidaksesuaian ini dimungkinkan karena sulitnya mendapatkan sampel yang representatif pada sediaan biopsi dan sulitnya penegakan diagnosis dari spesimen biopsi yang terlalu kecil. 
Distribusi Adenokarsinoma Prostat Berdasarkan Kesesuaian Diagnosis Klinis dengan Diagnosis Histopatologi

Dari 84 kasus adenokarsinoma prostat di Laboratorium Patologi Anatomi RSUD Dr. Saiful Anwar Malang pada tahun 2015-2019, didapatkan 55 kasus $(65,48 \%)$ dengan diagnosis/keterangan klinis yang sesuai dengan pemeriksaan histopatologinya dan sisanya sekitar 22 kasus $(26,19 \%)$ kurang sesuai atau kurang akurat, sedangkan 7 $(8,33 \%)$ kasus tidak didapatkan keterangan klinis.

Adenokarsinoma prostat dapat dideteksi sejak awal dari pemeriksaan fisik berupa gangguan pengeluaran air seni, adanya abnormalitas pada pemeriksaan colok dubur, dan didukung dengan peningkatan nilai kadar prostate specific antigen (PSA). Hal ini membuktikan bahwa secara umum keluhan yang mengarah pada adenokarsinoma prostat sebelum dilakukan pemeriksaan histopatologi dapat diprediksi dengan anamnesis, pemeriksaan fisik, maupun pemeriksaan penunjang berupa kadar PSA. Meskipun banyak pula yang asimptomatis dan disebutkan dalam literatur terdeteksi secara tidak disengaja saat otopsi.5,9

Hasil penelitian ini sesuai dengan penelitian sebelumnya bahwa kemudahan melakukan diagnosis klinis sebelum pemeriksaan histopatologi membuat tingginya angka kesesuaian antara diagnosis klinis dan diagnosis histopatologi. Angka kematian pada kanker prostat dilaporkan telah menurun meskipun diagnosis meningkat. Kematian akibat kanker prostat di AS telah turun sekitar 40\% sejak 1993, dari 38,6 menjadi 24,6 per 100.000. Penurunan ini dsebabkan oleh peningkatan deteksi dini dan terapi. ${ }^{10}$

Beberapa spesimen masih ada yang terdiagnosa sebagai lesi jinak dan terbukti sebagai adenokarsinoma prostat dengan pemeriksaan histopatologi. Hal ini dapat disebabkan karena anamnesis dan pemeriksaan fisik pada adenokarsinoma prostat sangat mirip dengan lesi jinak lainnya, termasuk benign prostat hyperplasia. Adanya proliferasi dari sel stromal pada benign prostate hyperplasia (BPH) menyebabkan pembesaran kelenjar tersebut sehingga terdeteksi sebagai abnormalitas pada pemeriksaan colok dubur. Manifestasi BPH dapat berupa terganggunya aliran urin, sulit buang air kecil (BAK), dan pancaran urin lemah, yang mirip sekali dengan keluhan pada adenokarsinoma prostat.9,11

Uji kadar PSA merupakan pemeriksaan sensitif untuk lesi pada prostat namun bukan pemeriksaan spesifik untuk adenokarsinoma prostat. Namun, semakin tinggi kadar PSA serum maka semakin tinggi pula kecurigaan adanya kanker prostat. PSA memiliki spesifikasi absolut untuk satu jenis jaringan, yaitu epitel kelenjar prostat dan diekspresikan oleh sebagian besar kanker prostat. Hanya sedikit kanker prostat yang mengekspresikan kadar PSA rendah atau tidak mengekspresikan PSA sama sekali, tetapi ini terjadi hampir secara eksklusif pada tumor yang tidak berdiferensiasi. ${ }^{12}$ PSA telah dipelajari secara ekstensif, dan saat ini digunakan sebagai penanda tumor pada pasien dengan kanker prostat yang dicurigai. Dengan adanya faktor risiko persisten (misalnya, peningkatan PSA), biopsi prostat berulang sering digunakan untuk mendeteksi kanker tersembunyi pada pria dengan temuan negatif sebelumnya. Sayangnya tidak semua kasus lesi prostat diperiksa kadar PSA dengan berbagai alasan. Hal-hal yang disebutkan di atas yang menyebabkan adanya ketidak sesuaian antara diagnosa klinis dengan diagnosa histopatologi. $9,10,13,14,15$

Distribusi Adenokarsinoma Prostat Berdasarkan Derajat Diferensiasi

Adenokarsinoma prostat yang ditemukan di Laboratorium Patologi Anatomi RSUD Dr. Saiful Anwar Malang periode tahun 2015-2019, kemudian didistribusikan pada skor Gleason. 
Masing-masing spesimen dikelompokkan derajat diferensiasinya menjadi 3 kelompok yakni, well differentiated, moderate differentiated, dan poorly differentiated. Distribusi adenokarsinoma terbanyak didapatkan pada derajat differensiasi poorly differentiated, dengan jumlah kasus sebanyak $46(54,76 \%)$.

Saat ini, skema Gleason adalah sistem penilaian yang paling banyak digunakan di Amerika Utara, dan juga digunakan secara ekstensif di seluruh dunia, untuk menilai grade adenokarsinoma prostat, klasifikasi WHO terbaru yang telah mendukung sistem Gleason, membuatnya lebih konsisten dipraktekkan di seluruh dunia. Keberhasilan grading system oleh Gleason dikaitkan dengan beberapa faktor. Pertama, ada data yang menunjukkan korelasi klinis yang kuat antara Gleason grading dan berbagai klinis, patologis, dan parameter hasil. Kedua, sistem Gleason relatif sederhana. Penilaian cukup didasarkan pada penilaian mikroskopis. Ketiga, tidak ada model histogenetik khusus untuk menggunakan sistem penilaian ini.2,9 Penentuan derajat keganasan kemudian ditentukan dari pengelompokan skor Gleason yang terdiri dari diferensiasi baik $(\leq 6)$, sedang/moderat (7), dan buruk (8-10).,2,16

Kanker prostat memiliki heterogenitas secara klinis dan mikroskopis, mencakup tumor indolen yang berdiferensiasi baik hingga tumor yang sangat agresif dan dapat menyebabkan morbiditas dan mortalitas yang cukup besar. Sayangnya lesi pada adenokarsinoma prostat banyak didapatkan pada zona perifer yang jarang sekali memberikan keluhan klinis, berbeda dengan benign prostat hiperplasi yang biasa terjadi pada zona sentral, sehingga pasien yang terdiagnosa datang dalam keadaan sudah memiliki derajat diferensiasi yang buruk. $17,18,19$

Distribusi Adenokarsinoma Prostat Berdasarkan Prognostic Group Grade

Adenokarsinoma prostat yang ditemukan di Laboratorium Patologi Anatomi RSUD dr. Saiful Anwar Malang periode tahun 2012-2019 dan terdistribusi pada skor Gleason selanjutnya akan dilakukan penilaian prognostic Gleason group grade. Distribusi prognostic Gleason group grade terbanyak didapatkan pada grup 4 sebanyak 25 $(29,76 \%)$ kasus. Disusul oleh prognostic group grade 5 sebanyak $18(21,43 \%)$.

Hal ini selaras dengan penentuan derajat keganasan dengan Gleason score system, bahwa semakin tinggi skor Gleason, semakin tinggi pula derajat keganasan, berpengaruh pula pada prognosis penyakit. Namun demikian masih didapatkan 32 kasus yang tidak didapatkan catatan skor Gleason, sehingga tidak dapat ditentukan prognostic group grade-nya. ${ }^{15,16}$

\section{Kesimpulan}

Penderita adenokarsinoma prostat di Laboratorium Patologi Anatomi RSUD Dr. Saiful Anwar Malang periode tahun 20152019 sebanyak $84(7,58 \%)$ kasus, memiliki rentang umur 52-88 tahun, dengan rata-rata usia 68 tahun. Paling banyak terdiagnosis dari spesimen kerokan, sebanyak 48 $(57,14 \%)$ kasus. Sebagian besar diagnosis klinis sesuai dengan hasil pemeriksaan histopatologinya yakni $55(65,48 \%)$ kasus. Derajat diferensiasi yang terbanyak adalah poorly differentiated sebanyak 46 (54,76\%) kasus, dan prognostic Gleason group grade terbanyak didapatkan pada grup 4 sebanyak $25(29,76 \%)$ kasus.

Dari penelitian ini disimpulkan bahwa adenokarsinoma prostat rata-rata terjadi pada usia 68 tahun, paling banyak didiagnosis pada bahan kerokan. Sebagian besar kasus memiliki kesesuaian antara diagnosis klinis dan diagnosis histopatologi. Kasus yang didiagnosis umumnya termasuk dalam kategori poorly differentiated dan prognostic Gleason group grade 4. 
Saran

Saran bagi klinisi, diharapkan pengisian formulir permintaan pemeriksaan histopatologi dapat dilengkapi sehingga dapat mendukung diagnosis histopatologi yang tepat. Selain itu, juga dapat digunakan sebagai data rekam medis baik untuk keperluan follow up diagnosis dan terapi bagi pasien maupun untuk keperluan penelitian lebih lanjut. Bagi ahli patologi anatomi agar lebih memperhatikan kelengkapan penulisan jawaban hasil pemeriksaan histopatologi termasuk penulisan grading sehingga dapat membantu klinisi memperkirakan prognosis dan memberikan terapi yang tepat juga agar dapat digunakan untuk keperluan penelitian lebih lanjut.

\section{Daftar Pustaka}

1. Joshee A and Sarma K. The Histomorphological Study of Prostate Lesions. Journal of Dental and Medical Sciences. 2015; 14:85-89.

2. Komite Penanggulangan Kanker Nasional. Panduan Penatalaksanaan Kanker Prostat. Kementerian Kesehatan Republik Indonesia. 2018.

3. Barnes RW. Survival with Conservative Therapy. JAMA. 1969; 210(2):331-332. doi:10.1001/jama.1969.03160280071017.

4. Badan Registrasi Kanker Perhimpunan Dokter Spesialis Patologi Indonesia. Kanker di Indonesia Tahun 2014 Data Histopatologik. Jakarta : Yayasan Kanker Indonesia. 2018

5. International Agency for Research on Cancer World Health Organization. Global on Cancer (Globocan) Indonesia. (Online). 2020. https://www.google.com/ url?sa=t\&source=web\&rct=i\&url=https:// gco.iarc.fr/today/data/factsheets/ populations/360-indonesia-factsheets. pdf\&ved=2ahUKEwiFkfGWg9DtAh Ud6nMBHTtTC7kQFiAAegQIAxAC\&usg=
AOvVaw2CxCbX3oRrh0RQ7oChc0Be

6. Shah RB and Zhou M. Prostate Biopsy Interpretation: Histologic Variants of Acinar Adenocarcinoma, Ductal Adenocarcinoma, Neuroendocrine Tumors, and Other Carcinomas. Switzerland AG: Springer Nature. 2019. P. 1-10.

7. Robinson BD, Mosquera JM, Ro JY, Divatia M. Precision Molecular Pathology of Prostate Cancer. Springer International Publishing AG. 2018. P. 38.

8. Holmberg L, Hemelrijck MV. Prostate Cancer Prevention: The Biology and Natural History of Prostate Cancer: A Short Introduction. Springer-Verlag Berlin Heidelberg. 2014. P. 9-13.

9. Humphrey PA, Amin M.B, Berney DM, et al. Acinar Adenocarcinoma in WHO Classification of Tumours of the Urinary System and Male Genital Organs. Eur Urol. 2016; 70(1):106-119. doi: 10.1016/ j.eururo.2016.02.028. Epub 2016 Mar 17.

10. Algaba F. Atlas of Multiparametric Prostate MRI: Pathology of Prostate Cancer. Springer International Publishing AG. 2018. P. 56.

11. Zynger DL and Parwani AV. Prostate Pathology. Demosmedical. 2015. P. 9091.

12. Klotz L. Active Surveillance for Localized Prostate Cancer A New Paradigm for Clinical Management. Springer International Publishing AG, 2018. P. 1319.

13. Shore ND, Ventii K. The Prostate Cancer Dilemma: Genomic Markers. Springer International Publishing Switzerland. 2016. P. 138-146.

14. Gion M, Trevisiol C, Rainato G, Fabricio ASC. One Metastases from Prostate Cancer : Markers of Prostate Cancer: The Role of Circulating Tumor Markers in the Management of Bone Metastases. Springer International Publishing Switzerland. 2017. P. 42-51. 
15. Putriyuni A dan Hilbertina N. Adenokarsinoma Prostat: Penilaian Prognostik dan Derajat Histopatologi. Jurnal MKA. 2014; 37: 2.

16. Amin MB, Humphrey PA, Grignon DJ, Srigley JR. Gleason Grading of Prostate Cancer A Contem porary Approach. Lippincott Williams \& Wilkins. 2004. P. 1-124.

17. Adelia F, Monoarfa A, Wagiu A. Gambaran Benigna Prostat Hiperplasia di
RSUP Prof. Dr. R. D. Kandou Manado Periode Januari 2014 - Juli 2017. Jurnal e-Clinic (eCl). 2017; 5:2.

18. Epstein JI dan Netto GJ. Biopsy Interpretation of The Prostate. Wolters Kluwer. 2015. P. 83-298.

19. Papadimitriou N, Critselis E, Tsilidis K. Energy Balance and Prostate Cancer: Incidence and Mortality. Springer International Publishing AG. 2018. P. 120. 